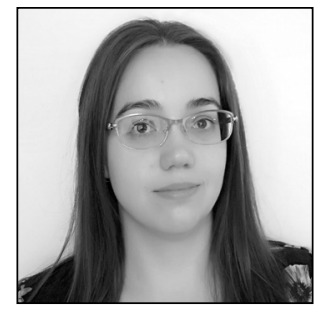

Katrin Kiirend-Pruuli

Doctoral student

University of Tartu

\title{
Personal Freedom in Estonian Marriage Law between 1918 and 1940
}

\section{Introduction}

Recently, the Republic of Estonia celebrated its centennial, 100 years since declaring its independence in 1918. Although the first, very modern and liberal Constitution of Estonia ${ }^{* 1}$ was established in 1920, many of the old, conservative laws that came before it from the time of the Russian Empire, such as the Baltic Private Law Code $(B P L C)^{*_{2}}$, remained in force during Estonia's first era of independence, in the 1920 and 1930s. Estonian lawyers and politicians swiftly began work to develop a new civil code. ${ }^{*}$ Different opinions collided in discussions about reforming the country's private law, including its family law and institution of marriage.

Marriage establishes a very tight personal and legal connection between two persons, and sometimes interests of a family can come into conflict with the personal freedom of one or the other spouse. In this article, the concept of personal freedom is understood thus: being free within society from oppressive restrictions and having the opportunity to conclude contracts or change one's legal status without undue constraint. Accordingly, one goal for those compiling a new Civil Code of Estonia was to find balance between modern, liberal ideas of personal freedom and traditional ideas about stability of marriage. Although there are a few publications about Estonian family law in the interwar era, ${ }^{*}$ none of them analyses the compromise between personal freedom and family stability in greater depth.

Eesti Vabariigi põhiseadus - RT 1920 113/114 (in Estonian).

2 There were official versions of the BPLC in both German and Russian. In German: Provincialrecht der Ostseegouvernements. Dritter Theil. Privatrecht. Liv-, Est- und Curlaendisches Privatrecht. (Zusammengestellt auf Befehl des Herrn und Kaisers Alexander II, Buchdruckerei der Zweiten Abtheilung Seiner Kaiserlichen Majestät Eigener Kanzlei, St. Petersburg 1864). The Russian version used for this article: Владимир Буковский, Сводъ гражданскихъ узаконений губерний прибалтийскихъ (Томъ 1, Рига 1914). This was the latest version made available and includes commentary, although it was not the official Russian version.

3 For more about the BPLC and attempts to modernise private law in interwar Estonia, see: Hesi Siimets-Gross, Marju LutsSootak, and Katrin Kiirend-Pruuli, 'The Private Law Codification As an Instrument for the Consolidation of a Nation from Inside - Estonia and Latvia between Two World Wars' in Michał Gałędek and Anna Klimaszewska (eds), Modernisation, National Identity and Legal Instrumentalism (Studies in Comparative Legal History, vol 1: Private Law Brill, Leiden). DOI: https://doi.org/10.1163/9789004417274_013.

4 Most of the publications are in Estonian - for example: Katrin Kiirend-Pruuli, ‘Abikaasade isiklike suhete õiguslik korraldus Eesti esimesel iseseisvusperioodil: tee kaheliikmelise parlamendi suunas' (Legal Regulation of Personal Relationships between Spouses during the First Period of Independence: a Way towards a Two-Member Parliament) [2017] Annales Litterarum Societatis Esthonicae 205; Toomas Anepaio, 'Varaühisus - kas nõukogulik igand' (Common Property - a Relic from the Soviet Times?) [2002] 3 Juridica 193; Katrin Roosileht, Vaeslastekohtud (Orphans' Courts) (Eesti Ajalooarhiiv, Tartu 2003); Merike Ristikivi, Marju Luts-Sootak, and Heli-Triin Räis, 'Kohtuniku amet on liiga raske neile: Eesti naisjuristide pürgimisest kohtunikuks kahe maailmasõja vahelisel perioodil' (A Judge's Profession is Too Difficult for Them: on the Aspiration of 
In the 1920s, Estonian family law was quickly liberalised in some respects. Estonia was one of the first countries in the region to legalise consensual divorce, doing so in 1923, and civil marriage was established in $1926 .{ }^{*} 5$ The interesting question in this connection is whether the new, modern and liberal ideas had any influence on personal and proprietary relations between spouses during the marriage as represented in the drafts for the civil code. This article examines the personal freedom of spouses from two perspectives: how much freedom the state gave the spouses to regulate their personal and proprietary relations and how much personal freedom the wife had when compared to the husband. For pinpointing the breadth and limits of personal freedom in marriage, the family law in force in the 1920 s and 1930 - the BPLC - will be analysed and compared with the Estonian Civil Code drafts. The drafts and related discussions help to illuminate the form and extent of personal freedom that was considered suitable for the new and modern state.

\section{Personal freedom in personal relations between spouses}

Personal relations between spouses were regulated by the BPLC's Article 11, stating that 'by marriage, the husband becomes a guardian (adviser or assistant) of the wife'. So the husband was the legal guardian of his wife. For example, the husband had the right to represent her in court proceedings, file claims on behalf of his wife without her authorisation, and participate in criminal proceedings when she was a victim (under Article 8). According to Article 7, the spouses were obliged to live together, and Article 8 entitled the husband to demand spousal obedience from his wife and choose the place of family residence.

In the course of the 1920 s and 1930s, several political, social, legal, and economic changes took place. The role of women in the public sphere changed considerably. While Article 6 of the Constitution of 1920 declared that all citizens are equal before the law, with men and women therefore being alike in this regard, that norm was applied only in public-law matters. ${ }^{*}$ The principle of equality between men and women in public law did exert pressure, though, encouraging demands for more equality in family law, and discussions frequently stressed arguments for a new position of women in public law. ${ }^{*}$

The first committee on record charged with drafting an Estonian Civil Code in place of the outdated BPLC was formed in $1923 .{ }^{*}$ It was not long before the Estonian Women's Union sent a note to the committee who were drafting the civil code. They strongly advised using the more modern and egalitarian Swedish

Female Estonian Lawyers to Become a Judge in the Period Between the World Wars) (2017) 2/3 Ajalooline Ajakiri 309. DOI: https://doi.org/10.12697/aa.2017.2-3.05; Marelle Leppik, 'Soolise võrdõiguslikkuse küsimus Eesti Vabariigi põhiseadustes ja riigikohtu praktikas 1920-1940' (The Issue of Gender Equality in the Constitution of Estonia and the Case Law of the Supreme Court in 1920-1940) (2017) 2/3 Ajalooline Ajakiri 341. DOI: https://doi.org/10.12697/aa.2017.2-3.06. Some aspects of Estonian family law are analysed in: Katrin Kiirend-Pruuli and others, 'Die Mesalliance des liberalen Eherechts mit dem konservativen Familienrecht im Estlands Recht der Zwischenkriegszeit' in Martin Löhning (ed), Kulturkampf um die Ehe - Die Reform des europäischen Eherechts nach dem Großen Krieg (Mohr Siebeck, Tübingen, forthcoming in 2020) (in German). DOI: https://doi.org/10.1628/978-3-16-159305-5.

5 See more about reforms in marriage and divorce law in: Katrin Kiirend-Pruuli and others (n One of the reforms IDD brought about was that regulation of the duty to give information was extended to cover not only insurance intermediaries but also insurers themselves - prior to IDD, regulation of the insurer's duty to give information to a customer was left mostly to national legislators. A noteworthy element in the IDD rules concerning the insurer's duty to give information is that the directive contains a detailed list of issues that must be notified to the customer (art 20(8) IDD). This legislative technique corresponds to that adopted in Directive 2009/138/EC on taking up and pursuing the business of Insurance and Reinsurance (Solvency II) in the field of life insurance (see art 185(3)) as well as that adopted in art 2:201 of the Principles of European Insurance Contract Law ('PEICL') as generally applicable. On the other hand, this technique deviates from the one customarily utilized in Nordic countries, where the content of the insurer's duty to give information has been defined with compact general clauses.).

6 Article 6 states that there 'cannot be any public privileges or prejudices derived from birth, religion, sex, rank or nationality. In Estonia there are no legal class divisions or titles'. For more, see: Hesi Siimets-Gross and Marelle Leppik, 'Estonia: First Landmarks of Fundamental Rights' in Markku Suksi and others (eds), First Fundamental Rights Documents in Europe (Intersentia 2015). DOI: https://doi.org/10.1017/9781780685281.024.

7 Malka Schliefstein, 'Uus perekonnaõigus tsiviilseadustiku ümbertöötamise komisjonis' (New Family Law in the Committee for Redrafting the Civil Code) [1930] 4 Naiste Hääl 51, 58; Boris Sepp, 'Naise eraõiguslik seisukord Balti eraõiguse ja uue eraõiguse kava järele' (Woman's Position according to the Baltic Private Law and the Draft of the New Private Law) [1929] 2 Naiste Hääl 25 (both in Estonian).

8 About the drafting process and the various committees involved in preparing Estonian Civil Code drafts, more details are provided in: Marju Luts-Sootak, Hesi Siimets-Gross, and Katrin Kiirend-Pruuli, 'Estlands Zivilrechtskodifikation - ein fast geborenes Kind des Konservatismus' in Martin Löhnig and Stephan Wagner (eds), Nichtgeborene Kinder der Liberalismus? - 
family law as a model and abolish husbands' guardianship over wives. ${ }^{*}{ }^{*}$ The drafters, exclusively male in that time, were far more conservative on the matter and preferred taking the BPLC and the significantly more conservative German and Swiss family law as models.

In 1926, the first draft of a family law was published as part of a draft civil code. ${ }^{*_{10}}$ The draft of $1926 \mathrm{did}$ not state expressly the concept of guardianship over wives, but its Section 358 provided that the husband is the representative of common life and the household. The de facto guardianship over the wife was limited to proprietary rights and representation in court proceedings, though (per §358's Subsection 2 and §380). The husband had the right to choose the family residence and decide on day-to-day matters, but the wife did not have to obey him when the husband abused his rights (\$356). ${ }^{* 11}$

The above-mentioned principles were discussed during Estonian Lawyers' Days in 1930. Outspoken female lawyer Elise Aron ${ }^{* 12}$ heavily criticised the draft, she considered it outdated, impractical, and incompatible with real life and everyday needs. ${ }^{{ }^{13}}$ Member of the draft committee Jüri Uluots ${ }^{* 14}$ explained in response that the law has to protect the family, which is 'an important building block of society', and that regulation is to strike a compromise between the interests of the husband and those of the wife. ${ }^{*} 15$ The compromise between 'family stability' and personal freedom is clearly evident here. The perspective of personal freedom was addressed even more clearly by Ants Piip ${ }^{* 16}$, who stated that Estonian laws regulating women's rights were among the most liberal in the world and that the foundation of marriage is formed not by an individual and his or her interests but by stability, as 'capricious demands for great personal freedom are unbecoming in married life. ${ }^{*}{ }^{17}$ A more extreme-sounding statement in this regard was made by legal practitioner August Leps ${ }^{*}{ }^{18}$, who said: 'It is unfeasible to demand that a family would be like a two-member parliament. In a family, it is necessary that the stance of one spouse be decisive and dominant.' However, he was more open to modern ideas than many others. He concluded that, when registering their marriage, the couple should be able to choose which of them will become the head of the family. ${ }^{*}{ }^{19}$ In summary, personal freedom was often seen as incompatible with gender equality in 1920 family law; nonetheless, some changes were made.

At first glance, the next draft, published in $1935,{ }^{* 20}$ seems to have been a huge step forward. Firstly, it did not dictate a man's guardianship over his wife. Secondly, the draft also stated that the husband and wife are equal in their right to choose the place of residence and decide on day-to-day matters (per §264's

Zivilgesetzbebung im Mitteleuropa der Zwischenkriegszeit (Mohr Siebeck, Tübingen 2018) (in German). DOI: https://doi. org/10.1628/978-3-16-156292-1.

9 'Kirjavahetus Eesti tsiviilseaduse eelnõu väljatöötamise ning sama komisjoni isikulise koosseisu küsimuses' (Correspondence on the Matters Regarding Drafting of the Draft Civil Code and the Composition of the Respective Committee), material from 15 January 1920 - 3 March 1921, Estonian National Archives (ENA) ERA.76.2.333 (in Estonian).

10 Tsiviilseadustik: üldosa ja perekonnaõigus (Civil Code: General Part and Family Law) (Tallinn 1926) (in Estonian).

11 Personal relations between husband and wife during the interwar period are analysed in greater depth in the work of: Katrin Kiirend-Pruuli, 'Abikaasade isiklike suhete õiguslik korraldus Eesti esimesel iseseisvusperioodil: tee kaheliikmelise parlamendi suunas' (Legal Regulation of Personal Relationships between Spouses during the First Period of Independence: a Way towards a Two-Member Parliament) [2017] Annales Litterarum Societatis Esthonicae 205 (in Estonian, with English summary).

12 Elise Aron (1896-1982) was a primary-school teacher in 1916-1920, after which she headed the Office for Legal Persons at the Ministry of the Interior until 1940. She actively criticised the civil code drafts.

13 Elise Aron, 'Abikaasade õiguslikkude vahekordade korraldamisest' (On Regulating Legal Relationships Between Spouses) in Jaanika Erne (ed), Õigusteadlaste päevad 1922-1940 protokollid (Juura 2008) 460-463 (in Estonian).

14 Jüri Uluots (1890-1945) was Professor for Legal History with the University of Tartu's law faculty (1925-1940), Dean of the Faculty of Law (1924-1931 and 1942 -1944), and a member of the Constituent Assembly and Estonia's parliament (Riigikogu).

15 Jüri Uluots, 'Tsiviilseadustiku eelkava alusmõtteist. Kokkuvõte referaadist' (On the Main Principles of the Preliminary Draft of the Civil Code. Abstract Summary) in Jaanika Erne (ed), Õigusteadlaste päevad 1922-1940 protokollid (Juura 2008) 456-457 (in Estonian).

16 Ants Piip (1884-1942) held the title Professor of International Law at the University of Tartu (1924-1940) and held various political offices: Prime Minister in 1920; State Elder (head of state) in 1920-1921; and Minister of Foreign Affairs in 1921-1922, 1925-1926, 1933, and 1939-1940.

17 Ants Piip in discussion about the Conference of Estonian Lawyers in: Jaanika Erne (ed), Õigusteadlaste päevad 1922-1940 protokollid (Juura 2008) 484 (in Estonian).

18 August Julius Leps (1896-1972) was an attorney and member of the Estonian parliament.

19 August Leps in discussion related to the Conference of Estonian Lawyers in: Jaanika Erne (ed), Õigusteadlaste päevad 1922-1940 protokollid (Juura 2008) 488 (in Estonian).

20 Tsiviilseadustiku 1935. a eelnõu (Draft Civil Code, 1935) (Tallinn 1935) (in Estonian). 
Subsection 1). However, the husband and wife still did not become completely equal. If the spouses were of diverging opinions, the husband's remained decisive and his wife's only recourse was to appeal to the court of custody ${ }^{* 21}$ to change the decision (under Subsection 2). This strange compromise was harshly criticised by women's organisations, who considered it unsatisfactory. ${ }^{* 22}$ Others supported the regulation, with Viljandi Circuit Court, for example, finding that absolute equality between husband and wife in all spheres of life would damage family stability. ${ }^{*} 3$ The regulation remained unchanged in the drafts of $1936^{* 24}$ and 1939. ${ }^{* 25}$ The last draft version was discussed by the parliamentary committee on civil law in $1940,{ }^{*} 26$ but the regulation was still to go unchanged. Regrettably, Soviet occupation reached Estonia in June 1940, before the Parliament of Estonia had finished discussing the draft, so a new civil code was never adopted. In practice, the BPLC remained in force throughout the first era of independence of Estonia.

The wife's right to dispute a decision by her husband before the court of custody is one of the most noteworthy compromises found in the drafts, a compromise between conservative traditions and liberal modernity, between personal freedom and family stability. However, it would have given this committee a very important role in regulating personal matters and created a possibility of intervening in family life. As the final decision would have been made by the state, the compromise would have restricted the personal freedom of both spouses. Newspaper reports stated that 'according to the BPLC, the wife was under the guardianship of her husband, but according to the draft, the husband is under the guardianship of the court of custody. ${ }^{*}{ }^{27}$

\section{Aspects of personal freedom in the statutory matrimonial property regime}

In the BPLC, the above-mentioned guardianship over the wife extended to proprietary relations. On account of matrimonial guardianship, the husband also administered all family property, including both the property his wife had owned before marriage and property that the spouses acquired during the marriage (per Article 12). Objects of property administered by the husband were deemed to be the husband's property, and the wife had to prove that any given item was hers in the event of a dispute (per Article 13). She was allowed to conduct only smaller transactions, related to day-to-day needs. ${ }^{*} 8$ These were general rules applicable to all of the various matrimonial property regimes that could be applied.

According to the BPLC, more detailed regulation addressing the matrimonial property regime depended on the region and the estate in question. ${ }^{* 29}$ As there were many regional exceptions to the BPLC, only two most important regimes remaining in force in the Republic of Estonia are analysed here. The first, called universal community property (varaühisus, Gütergemeinschaft), was the statutory matrimonial property

21 The court of custody was not an ordinary court but an administrative committee dealing with specified family matters, such as guardianship over minors or disabled people. For further discussion, see: Katrin Roosileht, Vaeslastekohtud (Orphans' Courts) (Eesti Ajalooarhiiv, Tartu 2003) 6-7 and 60-67; Merike Ristikivi, Marju Luts-Sootak and Heli-Triin Räis, 'Kohtuniku amet on liiga raske neile: Eesti naisjuristide pürgimisest kohtunikuks kahe maailmasõja vahelisel perioodil' (A Judge's Profession is Too Difficult for Them: on the Aspiration of Estonian Female Lawyers to Become a Judge in the Period Between the World Wars) (2017) 2/3 Ajalooline Ajakiri 327-329 (both in Estonian).

22 Tsiviilseadustiku 1935. aasta eelnõu arvustusi ning täiendus- ja parandusettepanekuid (Opinions on and Suggestions for Amendment and Review of the 1935 Draft Civil Code) (Tallinn 1935) 31; Olinde Ilus, 'Mõnda meie perekonnaõiguse väljatöötamisest ja naiste osast selles' (On Drafting of Our Family Law and the Women's Role in It) Päevaleht (Tallinn, 23 November 1935) 10 (both in Estonian).

23 Tsiviilseadustiku 1935. aasta eelnõu arvustusi (Opinions on the 1935 Draft Civil Code) (n 22) 89-90.

24 Tsiviilseadustiku 1936. a. eelnõu (1935 Draft Civil Code) (Tallinn 1936) (in Estonian).

25 Ibid.; Tsiviilseadustik: Vabariigi Valitsuse ettepanek 11. XII 1939 (Civil Code: 11 XII 1939 Proposal of the Government of the Republic) (Tallinn 1939) (in Estonian).

26 Lembit Saarnits (ed), Tsiviilseadustik (Civil Code). 1940 (Tartu 1992) (in Estonian).

27 'Juristid jätkasid tsiviilseadustiku kawa arvustamist' (Lawyers Continue to Criticise the Draft Civil Code) Postimees (Tartu, 29 October 1936) 7 (in Estonian).

28 BPLC arts 56, 88, and 133.

29 The BPLC was not classical codification, as various old regional differences between town laws and land laws were preserved. For details, see: Toomas Anepaio, 'Varaühisus - kas nõukogulik igand' (Common Property - a Relic from the Soviet Times?) [2002] 3 Juridica 193 (in Estonian); on the regional differences and estate varieties under the BPLC in general, see: Marju Luts, 'Private Law of the Baltic Provinces As a Patriotic Act' [2000] 5 Juridica International 157, 160-163. 
regime for those subject to the jurisdiction of Livonian town law (see Article 79$)^{*} 30$ and Narva town law (see Article 109). Before gaining of independence, similar regulation was applicable for Livonian rural clergymen who did not belong to the noble class (see Article 67). There were some minor distinctions between regions, but, in general, all property of the spouses, irrespective of whether it was acquired before versus during the marriage, formed 'one conglomerate of property" ${ }^{\prime *}{ }^{1}$ - an aggregate entity that was jointly owned by the two spouses (see articles 68 and 80). The husband administered the common property that was considered to be universal community property (under articles 71 and 82), but he could not sell or pledge real estate without his wife's consent (per articles 72 and 83). When a marriage ended, each spouse was entitled to half of the common property (under Article 69).

The regime termed 'administration and usufruct' (varaühendus, Verwaltungsgemeinschaft) was the statutory matrimonial property regime applied in territories where Estonian town law ${ }^{*} 32$ or Estonian and Livonian land law were applicable. Here, the spouses' property did not form an aggregate entity, and both spouses owned their property separately. Nonetheless, the wife's property was administered by the husband in this case too. He could not only administer but also use his wife's property, whether it was acquired before or during the marriage (see articles 41 and 96-98). The wife's rights to administer her property on her own were put 'on hold' (under Article 53), although in this regime too the husband could not sell or pledge her real estate without her consent (see Article 99). When a marriage ended, both spouses were entitled to their own property (see articles 60 and 102).

The husband's right to use and administer the wife's property was universal and even encompassed a right for the husband to file a claim against his wife for that property. According to one ruling of the Estonian Supreme Court, from 1933, in cases of the wife and husband having separate places of residence and the wife leaving, taking some movable items belonging to her, the husband was entitled to file a claim to demand restoration of possession. As the husband decided on the mutual place of residence and had a right to administer the property, he had the right to determine the location of his wife's property. ${ }^{*} 33$

Some exceptions were applicable in both property regimes. The husband was not permitted to administer his wife's 'special property', under articles 27 and 41. This category included everything that 1) the wife had expressly reserved for her own administration and use from the property she brought into the marriage; 2) was given to her, by whomever, on condition of her own administration and use; 3) the wife acquired for herself with her husband's permission by using her own money or otherwise via her work or handicraft skills; 4) she received from her husband as 'pocket money or needle money"34; and 5) she saved from the fruits and income arising from this special property of her own.

According to commentary on the BPLC, the wife could make a unilateral declaration that she intended to reserve some of her property as her special property, without the husband's consent being necessary. Lawyers were not unanimous on whether this declaration had to be expressed in a marital property contract or could be in some other form ${ }^{*} 35$, but the Estonian Supreme Court resolved the matter by stating in 1931 that a marital property contract was indeed needed for this. ${ }^{*} 36$ Although a wife generally did not need her husband's authorisation for contracts, she was not totally independent in administration of her own property. The above-mentioned unilateral declaration to reserve some items as her special property could be expressed only on the occasion of entering into marriage. Later, the husband's consent was needed for this action. Also, items that the wife acquired through her own work or otherwise via handicraft skills were deemed the wife's special property only if the husband had previously consented to

30 The cities of Tartu, Viljandi, Võru, and Valga, all in the southern part of Estonia; Pärnu, in the West; and Kuressaare, on the island Saaremaa.

31 The concepts of einzige Masse (art 68) and gesamte Masse (art 80) are used in the German-language version.

32 Estonia's capital, Tallinn (Toompea hill excluded), plus Haapsalu and Rakvere, in the northern part of the country.

33 A. Peep (ed), I Abieluseadus Rïgikohtu tsiviilosakonna seletustega, II perekonnaõiguse (Balti Eraseaduse I. $r$ §§ 1-528) alal antud Riigikohtu tsiviilosakonna seletusi (I Marriage Act with the Explanations from the Civil Chamber of the Supreme Court, II Explanations from the Civil Chamber of the Supreme Court on Family Law (Baltic Private Law Code I. r §§ 1-528) (Tallinn 1937) 45 (in Estonian).

34 Pocket money or needle money (Taschen- oder Nadelgeld) was a small amount of money paid by the husband that the wife could use for her personal expenses.

35 Владимир Буковский, Сводъ гражданскихъ узаконений губерний прибалтийскихъ (Томъ 1, Рига 1914) 45, статья 27 пункты (б), (л) (in Russian).

36 A. Peep (n 33) 47. 
this being so. ${ }^{*}{ }^{37}$ In addition, a wife needed her husband's consent if wishing to work outside the household (per Article 4194), and if she wanted to conclude a contract to encumber immovables included in her special property, her husband also had to sign the contract or at least authorise this later (see Article 29). In the absence of the husband's signature, the contract was not void per se, but the wife could refuse fulfilment of her duties. ${ }^{*} 38$

For the draft of 1926, based mostly on the BPLC, some modifications were made, with Swiss and German laws adopted as models. In the $1926 \mathrm{draft}$, the statutory matrimonial property regime mandated was 'administration and usufruct' (\$379), which was very similar to the administration and usufruct regime specified in the BPLC. A wife could own property, but her rights to administer her property during the marriage were, again, 'on hold'. The husband administered the family property, and the wife was not permitted to conclude any contracts, even with property she owned before getting married, with the exception of small-scale contracts for meeting day-to-day needs (see §380 sq., §395, and §358, Subsection 2).

In a similarity to the BPLC system, a husband could not administer his wife's special property ( $\$ 367$ $s q$.), where the concept of the wife's special property remained mostly the same. The only difference from the BPLC was that his consent was not needed for working outside the household ${ }^{*} 39$ or for the wife's transactions with immovables belonging to her special property.

As noted above, the draft of 1926 was heavily criticised. Some female lawyers even considered it unconstitutional. ${ }^{*}{ }^{\circ}$ Women's organisations found that the statutory matrimonial property regime should allow the two spouses to administer the marital property equally, ${ }^{*}{ }^{41}$ but justness and 'marital unity' were also considered important. ${ }^{*} 2$ In 1931, a campaign to collect signatures against the outdated family law in force and for drafting of a new code was initiated. Ultimately, 32,000 signatures were obtained, which was more than expected. The signatures were sent to the Ministry of Courts with an explanatory letter and demands for more modern family law. ${ }^{*} 43$

Those amendment proposals by women's organisations that pertained to the matrimonial property regime were more successful than the ones addressing personal relations. The draft of 1926 was sent back to committee for changes. As proposals from women's organisations were taken into account and Hungarian law was supposedly used as a model ${ }^{*} 44$, the statutory matrimonial property regime was changed to the 'community of acquests and gains' system (per \$285) in the 1935 draft. This regime was seen as a combination of separate property and common property. In this system, each spouse was allowed to conclude contracts with his or her own property while married, regardless of whether it was acquired before marriage rather than in the time since (see $\S \S 284$ and 292). In the event that the marriage ended, the wife was to receive half of the assets acquired by the husband in the course of the marriage and the husband, likewise, would get half of the assets she acquired during the marriage. In cases of a childless marriage, this amount was set to a quarter instead of half (see §297). Female lawyers opined that having separate property during the marriage and sharing the acquests and gains if the marriage ends should help to harmonise personal freedom between the spouses and promote the family's unity. ${ }^{*} 45$

37 For example, if the wife had established a tailor's shop with her husband's consent: Владимир Буковский (n 35) 45, статья 27 пункты (a), (г).

38 И. М. Тютрюмов, Гражданское право (второе издание, Тарту, Типография Г. Лаакманъ 1927) 516 (in Russian).

39 Elmar Ilus, Tsiviilõiguse eriosa: autoriseeritud konspekt (Special Part of the Civil Code Act: Authorised Notes) (Tartu: Akadeemiline Kooperatiiv 1938) 20 (in Estonian).

40 Elise Aron (n 13) 463-464; Helmi Jansen, 'Miks on meil vaja uut perekonnaseadust?' (Why Do We Need a New Family Law?) [1927] 2 Naiste Hääl 30-32; Malka Schliefstein (n 7) 55 (in Estonian).

41 See page 1 of: Väljavõte Eesti Üleriikliku Naiskongressi poolt 2. novembril 1930. a vastu võetud resolutsioonidest (Extract of Resolutions Taken by the National Womens' Congress on 2 November 1930). ENA. ERA 76.2.148.

42 Elise Aron (n 13) 471.

43 'Naiskoondiste märgukiri Vabariigi Valitsusele uue perekonnaõiguse eelnõu vastu' (Memorandum of Womens' Associations to the Government of the Republic Opposing the New Draft Family Law) [1931] 7/8 Naiste Hääl 99-100; Timotheus Grünthal, 'Märkmeid eesti perekonnaseaduse eelnõu kohta. Abikaasade isiklikud ja varanduslikud vahekorrad' (Notes on the Draft of Estonian Family Law. Personal and Pecuniary Relationships Between Spouses) [1932] 4 Õigus 145, 148-149 (both in Estonian).

44 Jüri Uluots, Seletuskiri tsiviilseadustiku 1935. aasta eelnõu nelja esimese raamatu juurde (Explanatory Memorandum to the First Four Books of the Draft of the 1935 Civil Code) (Tartu 1936) 50 (in Estonian).

45 Vera Poska-Grüntal, 'Ungari perekonnaõiguse eelnõu osa abikaasade varaõiguse kujundamisel Eesti uues perekonnaõiguses' (The Part of Draft Family Law of Hungary in Shaping the Proprietary Rights of Spouses in Estonia's New Family Law) [1934] 8 Õigus 374, 375 (in Estonian). 
Although the new system seemed fair and modern, it prompted considerable discussion and critique. Opponents considered the system incompatible with the real world, complicated, strange and unknown. ${ }^{*} 46$ Some of them even suggested opting for separate property as the statutory matrimonial property regime since this solution would be at once modern and the easiest to understand. ${ }^{*} 47$ Arguments related to personal freedom were not explicitly used in these discussions. The criticisms notwithstanding, the community of acquests and gains remained the statutory matrimonial property regime articulated in the following drafts (see 278 of that from 1936 and $\S 315$ of the 1940 version). A separate property system would indeed have been easier to understand, and it would have given the spouses even more personal freedom in the proprietary sphere, but it also might have led to unjust consequences. If one spouse had a farmstead and the other worked there and helped to increase the value of the farm, application of a separate property system would leave the latter spouse not entitled to any compensation after divorce.

In the BPLC and in the draft of 1926 both, the wife's personal freedom in the proprietary sphere was highly restricted. While she possessed a right to own property, the statutory regimes restricted her capacity to conduct transactions, whether with her own property or involving marital property. Although the regulation of wife's special property increased wife's personal freedom, it often did not have great practical importance. Only in the richest families did the wife hold personal real estate or other expensive items; for most people, the wife's special property consisted only of her personal belongings used for everyday needs. Also, any opportunities for a wife to accrue further personal property during the marriage, by such means as working outside the home or starting a business, were subject to her husband's consent. Hence, the wife was still dependent on her husband and lacked personal freedom with regard to property. The new matrimonial property regime found in the $1935 \mathrm{draft}$, the community of acquests and gains, was more equitable, as both spouses could freely conclude transactions with their property.

New responsibilities were accompanied by new rights. As the wife's legal capacity was extended in respect of marital property, she became responsible for maintaining the family besides husband. This marks a contrast against the BPLC, under which the husband was the primary party responsible for this, seeing to his wife and children's needs irrespective of the wife's financial position. Husband also could not use gains derived from his wife's property entirely as he pleased - their use had to be dedicated to satisfying the family needs. ${ }^{*}{ }^{48}$ Regulation remained similar to the latter in the draft of 1926 (per $\S \S 359,369$, and 370) but changed markedly with the 1935 one, under which the responsibility was shared between husband and wife. Both spouses had to maintain the family to the best of their ability (see Subsection 1 of §269).

\section{The marital property contract as a tool to increase personal freedom}

The possibility of concluding a marital property contract can be seen as a way of granting more personal freedom to both spouses in that the contract gives them an opportunity to regulate their proprietary relations differently than in the manner pursuant to a particular statutory matrimonial property regime. Under the BPLC, marital property contracts were to regulate only proprietary relations (per Article 37). Conditions regulating personal relations, such as terms freeing a husband of his duty to maintain the family or eliminating the wife's duty to follow her husband to his chosen place of residence, were void. ${ }^{*} 49$ According to the BPLC's Article $37 s q$., the spouses were free to design the conditions of the contract: the contract did have to be in accordance with good morals, the aim of the marriage, and legal norms, but there were no other restrictions. With regard to community property, it was possible to declare some items special property of the husband or wife (see articles 70, 82, and 94). Eliminating the condition of the husband's guardianship

46 Hugo Vihalem, ‘Abikaasade varavahekord Tsiviilseadustiku 1935. a. eelnõu järgi' (Proprietary Relationships of Spouses According to the 1935 Draft Civil Code) [1935] 9 Õigus 404, 422-424 (in Estonian).

47 Hugo Vihalem, 'Abikaasade varavahekord Tsiviilseadustiku 1935. a. eelnõu järgi' (Proprietary Relationships of Spouses According to the 1935 Draft Civil Code) [1935] 10 Õigus 459, 462-463; Leo Leesment, 'Tsiviilseadustiku 1936. a. eelnõusse puutuvaid küsimusi' (Issues Regarding the 1936 Draft Civil Code) [1937] 3 Õigus 133, 135-136 (both in Estonian).

48 BPLC art 9 and art 199, Владимир Буковский (n 35) 55 статья 41 пункт (б); 149 статья 199 пункт (б); И. М. Тютрюмов (n 38) 512.

49 Владимир Буковский (n 35) 52-53 статья 37 пункты (б), (е). 
over his wife in the proprietary sphere was possible too, ${ }^{*}{ }^{50}$ as was agreement that the wife would administer the marital property in the husband's stead or that the property would be administered partly by the wife and partly by the husband. ${ }^{*}{ }^{1}$ Concluding marital property contracts became more popular as the era of independence progressed. Before 1918, there were only a few marital property contracts each year. These contracts became more popular after gaining of independence and by the end of 1930 there were more than 2,500 of them. ${ }^{*}{ }^{2}$ Marital property contracts were more common amongst richer people, but they did gain popularity for farmers in rural areas. For the most part, couples opted for the separate property system since the statutory matrimonial property regime was considered unjust and too difficult to understand. ${ }^{*} 53$ There have been suggestions also that general changes in society might be the reason behind the latter choice. Getting a divorce became easier, ties between husband and wife weakened, and women grew more independent and had greater opportunities for self-realisation, so wives did not want husbands to administer their property. ${ }^{*} 5$

The marital property contract was also regulated in the draft of 1926, similarly, the contract had to be in accordance with good morals and the purpose of married life, and it had to regulate only proprietary relations (under \$375). In one difference from the BPLC, the spouses were obliged to choose one of the matrimonial property regimes specified by law (see §372's Subsection 2). Instead of the statutory matrimonial property regime (the regime of "administration and usufruct") it was possible to choose, alternatively, separate property, ${ }^{*} 55$ universal community property ${ }^{*}{ }^{6}$, or limited community property ${ }^{*} 57$ as the regime. Thus, the draft of 1926 was in at least one respect more restrictive than the BPLC: the spouses' freedom to pick the manner of their proprietary relations was limited to the regimes presented in the law. It was not possible to 'invent' new property regimes. The model for the latter change was Swiss law, and arguments to do with protecting third parties and providing legal clarity were cited as reasons for the change. ${ }^{*} 58$

The principle remained the same in the draft of 1935 (see Subsection 2 of §288). Instead of statutory matrimonial property regime (the community of acquests and gains), a couple could choose the regime 'community of personal and marital property" 59 , separate property, or a system of universal community property ${ }^{* 60}$ (§286). Just as under the previous draft it was not allowed to 'invent' new property regimes. The main motivation cited for these restrictions was similar to that indicated for the 1926 draft: protecting third parties. ${ }^{*}{ }^{*}$ The same possibilities remained in the drafts of 1936 (§§ 278-279) and 1940 ( $\S 315-316$ ).

A marital property contract can be regarded as a tool to increase the spouses' personal freedom, especially that of the wife, at least in the proprietary sphere. However, the partners' personal freedom to determine the conditions of the contract was restricted in the drafts of the civil code. The reasons behind the restriction were stated to be the above-mentioned desire for legal clarity and need to protect third parties.

50 Ibid, 52-53 статья 37 пункт (б).

51 Ibid, 53 статья 38 пункт (б).

52 Mihkel Uesson, 'Abielurahva varanduslik vahekord ja abieluvaranduslikud lepingud' (Proprietary Relationships and the Respective Contracts Between Spouses) [1930] 5 Õigus 221, 223 (in Estonian).

53 Hugo Vihalem in 10 Õigus 459) (n 47) 459; Timotheus Grünthal, 'Märkmeid Eesti perekonnaseaduse eelnõu kohta. Abikaasade isiklikud ja varanduslikud vahekorrad' (Notes on the Draft Family Law of Estonia. Personal and Proprietary Relationships Between Spouses) [1932] 4 Õigus 145, 158 (in Estonian).

54 Mihkel Uesson (n 52) 223-224.

55 Separate property ('varalahusus'; see $\S \S 405$ and 406) - both spouses independently owned and administered all property they had before marriage or that they gained in the course of the marriage.

56 Universal community property ('üldine varaühisus'; see $\S \S 413$ and 415) - all property acquired by the spouses before or during the marriage was owned jointly by both spouses and administered by the husband.

57 Limited community property ('piiratud varaühisus'; see $\S \S 435$ and 436) was similar to universal community property except that some items of property or some types of things (e.g., real estate) were excluded from community property by matrimonial contract. It was also possible to limit community property to items acquired by the spouses during the time of marriage.

58 Page 102 of: 'Tsiviilkomisjoni koosolekute protokollid nr 151-350: pärandusõiguse, asiõiguse, perekonnaõiguse lugemine J. Uluotsa ettekandel' (Minutes No. 151-350 of the Civil Chamber's Meetings: Readings on Inheritance Law, Real Right, Family Law by J Uluots) materials, 21 May 1926 - 4 April 1929. Archive of Jüri Uluots. F 164, s 8, protocol 285.

59 The 'community of personal and marital property' system was a new regime. All property the spouses had before marriage or acquired during the marriage constituted their marital property. Both spouses remained owners of the property they held before being married, while property acquired during the time of marriage was jointly owned by the two spouses. All the marital property was administered by the husband, but the wife's consent was needed for transactions in the wife's real estate or securities (per §§ 313-318 and 320).

60 The regulation of separate property and universal community property remained mostly the same.

61 Jüri Uluots (n 44) 52. 
Although a marital property contract could increase personal freedom, it was considered too liberal and, in this, somewhat dangerous. The possibility of choosing from among four distinct matrimonial property regimes was sometimes regarded as too difficult and even harmful for the average citizen, as comparing regimes and choosing between them could prove to be the first step toward breaking up the marriage, should the spouses later be dissatisfied with their choice. Leo Leesment ${ }^{*} 62$ even offered the criticism that having so many proprietary systems in the law is 'an exaggerated expression of unlimited liberalism'. ${ }^{63}$

\section{Conclusions and final remarks}

In the first decades of the twentieth century, personal freedom in the marital sphere was quite restricted in Estonia, especially for the wife. Under the BPLC, the husband was the legal guardian of his wife and also had the right to decide on day-to-day matters and administer the family property. It was possible to grant the wife more personal freedom in the proprietary sphere by concluding a marital property contract, but personal relations could not be legally modified.

The new social and economic situation emerging in this young state in the 1920 s and 1930s, the strong mark of the new Constitution of Estonia in 1920, equal rights in the public sphere, and liberal Scandinavian model laws encouraged demands for more personal freedom in family law. In discussions about amendment proposals argument of protecting family's stability was often employed to restrict the personal freedom of one or both spouses. Nevertheless, many changes took place as legislators found a new balance between personal freedom, on one hand, and state interests, family stability, and legal clarity, on the other.

Firstly, matrimonial guardianship over women was abolished, yet the husband kept his leading role in deciding on everyday matters of family life. Why didn't the committee drafting the civil code go a step further and grant the husband and wife completely equal footing? In general, ideas connected with equal rights were widely accepted, but the conservative models of German and Swiss family law, coupled with conservative personal opinions of influential politicians and drafters of law, held Estonia back from moving toward more modern family law. Too much equality was considered threatening to family stability, so compromise between personal freedom and family stability became evident in this regard.

Secondly, the statutory matrimonial property regime was changed with the draft of 1935. Establishing the community of acquests and gains in place of the 'administration and usufruct' regime was a significant advancement toward more equality and personal freedom for the wife in family law - both spouses could now conclude contracts involving their property. It is significant also that the matrimonial property regime established in the 1935 draft did not just increase the wife's personal freedom. It also expanded her duties, in that the wife also became responsible for providing maintenance to family.

The personal freedom of spouses diminished in drafts of civil code only with regard to marital property contracts: the spouses became restricted to choosing one of the four property regimes set forth by law. Even the freedom to choose from among this array of regimes was considered somewhat dangerous. That said, the change was considered necessary to protect third parties and increase legal clarity.

From the perspective of personal and proprietary relations between spouses, numerous changes were stated by the final draft of the Estonian civil code relative to the BPLC. Most of these affected the legal position of the wife, among them abolishing legal guardianship over wives and changing the statutory matrimonial property regime. If the draft Estonian Civil Code had been adopted as law, the resulting family law would have been equal, free, and liberal in comparison with the BPLC, although there would still have been room for improvements to meet the demands of women's organisations.

62 Leo-Johann Leesment (1902-1986) was a lecturer and associate professor of civil law at the University of Tartu.

63 Leo Leesment (n 4747) 136. He suggested that there should be only one matrimonial property regime - separate property in addition to which a possibility could be offered to conclude a marital property contract. 